Electronic Supplementary information for

\title{
Dual-Functional NIR AIEgens for High-Fidelity Imaging of Lysosome in Cells and Photodynamic Therapy
}

Yanpeng Dai, Fangru He, Hefang Ji, Xinxin Zhao, Saima Misal, Zhengjian Qi* Jiangsu Province Hi-Tech Key Laboratory for Biomedical Research, School of Chemistry and Chemical Engineering, Southeast University, Nanjing, Jiangsu 211189, PR China E-mail address: qizhengjian@seu.edu.cn

\section{Contents}

1. Materials and instruments.

2. Spectral measurements.

3. Synthesis and structure characterization of AIEgens.

4. The synthetic scheme of MPAA, MPAN and MPAT.

5. Analysis and fluorescence bio-imaging figures.

6. Tables of photophysical data of AIEgens.

7. The characterization data of AIEgens.

8. Reference. 


\section{Materials and instruments}

All chemical reagents, biological samples and materials are obtained from commercial suppliers, and all chemicals are not pretreated unless otherwise specified. The silica gel (300-400 mesh, China Qingdao Haiyang Chemical Co.) was used for the compound purification. NMR ${ }^{1} \mathrm{H}$ and ${ }^{13} \mathrm{C}$ spectral data of the compounds were measured on an AVANCE III HD $600 \mathrm{MHz}$ (Bruker). Mass and IR spectral data of the compounds were obtained on an Agilent 6120 LCMS and Thermo Nicolet 5700, respectively. The UV-vis absorption and fluorescence emission data of the solution and solid were conducted on a UV-3750 spectrophotometer (Shimadzu) and a PluoroLog 3-TCSPC FluoroMax-4 spectrofluorometer (Horiba), respectively. The fluorescent images pictures of living cells and zebrafish were filmed on an Olympus FV3000 confocal microscopy (Japan). The fluorescence images of nude mice were taken on a Caliper IVIS Lumina III imaging system.

\section{Spectral measurements}

The stock solution of MPAA, MPAN and MPAT were prepared in DMSO (5 mM) and transferred according to the experiment. The solutions of metal ions $\left(\mathrm{Na}^{+}, \mathrm{K}^{+}, \mathrm{Li}^{+}\right.$, $\mathrm{Zn}^{2+}, \mathrm{Ca}^{2+}, \mathrm{Mg}^{2+}, \mathrm{Al}^{3+}, \mathrm{Cu}^{2+}, \mathrm{Fe}^{3+}, \mathrm{Ni}^{2+}$ and $\left.\mathrm{Mn}^{2+}, 5 \mathrm{mM}\right)$, anions (ClO- $\mathrm{HS}^{-}, \mathrm{HSO}_{3}{ }^{-}$, $\mathrm{SO}_{3}{ }^{2}-, \mathrm{NO}_{2}{ }^{-}, \mathrm{Ac}^{-}$and $\mathrm{H}_{2} \mathrm{O}_{2}, 5 \mathrm{mM}$ ) and amino acids (Cys, Hcy and $\mathrm{GSH}, 5 \mathrm{mM}$ ) were prepared in distilled water, respectively. The Phosphate Buffered Saline (PBS) solution was formulated with $\mathrm{KH}_{2} \mathrm{PO}_{4}$ and $\mathrm{Na}_{2} \mathrm{HPO}_{4}$, and adjusted to $\mathrm{pH}=7.4$ with $\mathrm{H}_{3} \mathrm{PO}_{4}$ solution. All spectra of the solution were obtained in a $1 \mathrm{~cm}$ wide quartz cuvette.

\section{Synthesis and structure characterization of AIEgens}

The compounds MPAB and HPAB were prepared according to methods reported in the literature ${ }^{[1]}$.

The HPAB (2.0 g, $6.55 \mathrm{mmol})$ and 4-(2-Chloroethyl)morpholine (2.68 g, 14.41 mmol) were dissolved in acetonitrile $(50 \mathrm{~mL})$, the $\mathrm{Cs}_{2} \mathrm{CO}_{3}(12.81 \mathrm{~g}, 39.30 \mathrm{mmol})$ and 
KI (217.47 $\mathrm{mg}, 1.31 \mathrm{mmol})$ were added to the reaction solution, then the mixture solution was stirred at $80{ }^{\circ} \mathrm{C}$ for $12 \mathrm{~h}$ under $\mathrm{N}_{2}$. After the reaction was completed and the solvent was removed under vacuum, the residue was washed with saturated saline $(200 \mathrm{~mL})$ and extracted with $\mathrm{DCM} / \mathrm{MeOH}(\mathrm{v}: \mathrm{v}=10: 1,30 \mathrm{~mL} \times 3)$, the organic phases were combined and dried over with anhydrous $\mathrm{Na}_{2} \mathrm{SO}_{4}$. The solution was filtrated and the solvent was removed, the crude product was purified by silica gel column (DCM: $\mathrm{MeOH}=100: 1)$ and give a light yellow viscous liquid (2.51 g, 51\% yield, MPAA). ${ }^{1} \mathrm{H}$ NMR $\left(600 \mathrm{MHz}, \mathrm{CDCl}_{3}\right) \delta 9.75(\mathrm{~s}, 1 \mathrm{H}), 7.64-7.61(\mathrm{~m}, 2 \mathrm{H}), 7.13-7.09(\mathrm{~m}, 4 \mathrm{H})$, 6.91-6.87 (m, 4H), $6.84(\mathrm{~d}, J=8.8 \mathrm{~Hz}, 2 \mathrm{H}), 4.11(\mathrm{t}, J=5.7 \mathrm{~Hz}, 4 \mathrm{H}), 3.75-3.73(\mathrm{~m}$, $8 \mathrm{H}), 2.81(\mathrm{t}, J=5.6 \mathrm{~Hz}, 4 \mathrm{H}), 2.59(\mathrm{~s}, 8 \mathrm{H}) .{ }^{13} \mathrm{C}$ NMR $\left(151 \mathrm{MHz}, \mathrm{CDCl}_{3}\right) \delta 190.44$, $156.55,154.11,139.13,131.55,128.15,128.01,127.63,117.04,115.83,115.72$, 67.04, 66.15, 57.76, 54.22. IR (KBr): 2922, 2851, 1690, 1678, 1592, 1558, 1541, 1502, 1330, 1242, 1161, 1116, 1050, 1037, 962, 914, 826, 775, 688, 626, 601, 552, 516, 478,454. MS (m/z): $[\mathrm{M}+2 \mathrm{H}]^{2+}$ calcd for: $\mathrm{C}_{31} \mathrm{H}_{39} \mathrm{~N}_{3} \mathrm{O}_{5}, 266.64$, found: 266.7 .

The MPAA (200 mg, $0.38 \mathrm{mmol})$ and malononitrile $(50 \mathrm{mg}, 0.75 \mathrm{mmol})$ were dissolved in DCM $(15 \mathrm{~mL})$, the $\mathrm{Et}_{3} \mathrm{~N}(76 \mathrm{mg}, 0.75 \mathrm{mmol})$ was added to the reaction solution, then the mixture solution was stirred at $25{ }^{\circ} \mathrm{C}$ for $6 \mathrm{~h}$ under $\mathrm{N}_{2}$. After the reaction, the solvent was removed under vacuum. The crude product was purified by silica gel column (DCM:MeOH=100:1) and give a dark red solid (150 mg, 68.7 \% yield, MPAN). ${ }^{1} \mathrm{H}$ NMR (600 MHz, $\left.\mathrm{CDCl}_{3}\right) \delta 7.69(\mathrm{~d}, J=9.0 \mathrm{~Hz}, 1 \mathrm{H}), 7.47(\mathrm{~s}, 1 \mathrm{H})$, $7.11(\mathrm{dd}, J=9.6,2.6 \mathrm{~Hz}, 2 \mathrm{H}), 7.08(\mathrm{~d}, J=8.5 \mathrm{~Hz}, 1 \mathrm{H}), 7.03(\mathrm{~d}, J=8.9 \mathrm{~Hz}, 2 \mathrm{H}), 6.91$ $(\mathrm{t}, J=6.1 \mathrm{~Hz}, 2 \mathrm{H}), 6.89-6.86(\mathrm{~m}, 1 \mathrm{H}), 6.85-6.82(\mathrm{~m}, 2 \mathrm{H}), 6.79(\mathrm{~d}, J=9.1 \mathrm{~Hz}, 1 \mathrm{H})$, $4.11(\mathrm{dt}, J=11.0,5.6 \mathrm{~Hz}, 4 \mathrm{H}), 3.76-3.73(\mathrm{~m}, 8 \mathrm{H}), 2.82(\mathrm{dd}, J=10.7,5.2 \mathrm{~Hz}, 4 \mathrm{H})$, 2.60 (s, 8H). ${ }^{13} \mathrm{C}$ NMR (151 MHz, $\left.\mathrm{CDCl}_{3}\right) \delta 157.92,157.15,155.43,154.19,149.30$, $140.70,138.09$, 133.28, 129.87, 128.26, 127.63, 127.04, 124.16, 121.96, 120.29, $116.86,116.00,115.75,115.65,114.50,112.49,74.40,66.99,57.81,57.70,54.20$. IR (KBr): 2219, 1658, 1641, 1612, 1567, 1541, 1502, 1442, 1321, 1295, 1242, 1191 , 1164, 1115, 957, 829, 725, 607, 486, 424. MS (m/z): $[\mathrm{M}+2 \mathrm{H}]^{2+}$ calcd for: $\mathrm{C}_{34} \mathrm{H}_{39} \mathrm{~N}_{5} \mathrm{O}_{4}$, 290.65, found: 290.7 .

The MPAA (300 mg, $0.56 \mathrm{mmol}$ ) and 1,3-indanedione (91 mg, $0.62 \mathrm{mmol}$ ) were 
dissolved in EtOH $(20 \mathrm{~mL})$, the piperidine $(48 \mathrm{mg}, 0.56 \mathrm{mmol})$ was added to the reaction solution, then the mixture solution was stirred at $85^{\circ} \mathrm{C}$ for $3 \mathrm{~h}$ under $\mathrm{N}_{2}$. After the starting material disappears, the solvent was removed under vacuum. The crude product was purified by silica gel column (DCM:MeOH=100:1) and give a dark red solid (300 mg, $80 \%$ yield, MPAT). ${ }^{1} \mathrm{H}$ NMR (600 MHz, $\left.\mathrm{CDCl}_{3}\right) \delta 8.38(\mathrm{~d}, J=8.9$ $\mathrm{Hz}, 2 \mathrm{H}), 7.94-7.90$ (m, 2H), 7.75 (s, 1H), 7.73 (dd, $J=4.9,3.6 \mathrm{~Hz}, 2 \mathrm{H}), 7.16-7.12$ (m, 4H), 6.92-6.89 (m, 4H), $6.86(\mathrm{~d}, J=9.1 \mathrm{~Hz}, 2 \mathrm{H}), 4.12(\mathrm{t}, J=5.6 \mathrm{~Hz}, 4 \mathrm{H}), 3.76-3.73$ $(\mathrm{m}, 8 \mathrm{H}), 2.82(\mathrm{t}, J=5.6 \mathrm{~Hz}, 4 \mathrm{H}), 2.60(\mathrm{~s}, 8 \mathrm{H}) .{ }^{13} \mathrm{C} \mathrm{NMR}\left(151 \mathrm{MHz}, \mathrm{CDCl}_{3}\right) \delta 191.56$, $189.86,156.82$, 153.55, 146.84, 142.46, 140.09, 138.73, 137.21, 134.76, 134.51, $128.22,124.84,124.67,122.84,117.06,115.86,67.05,66.23,57.76,54.24$. IR (KBr): 1672, 1666, 1623, 1555, 1501, 1441, 1382, 1320, 1242, 1181, 1152, 1114, 1085, 991, 830, 734, 662, 589, 512, 480, 437. MS (m/z): $[\mathrm{M}+2 \mathrm{H}]^{2+}$ calcd for: $\mathrm{C}_{40} \mathrm{H}_{43} \mathrm{~N}_{3} \mathrm{O}_{6}$, 330.66, found: 330.8 .

\section{The synthetic scheme of MPAA, MPAN and MPAT}

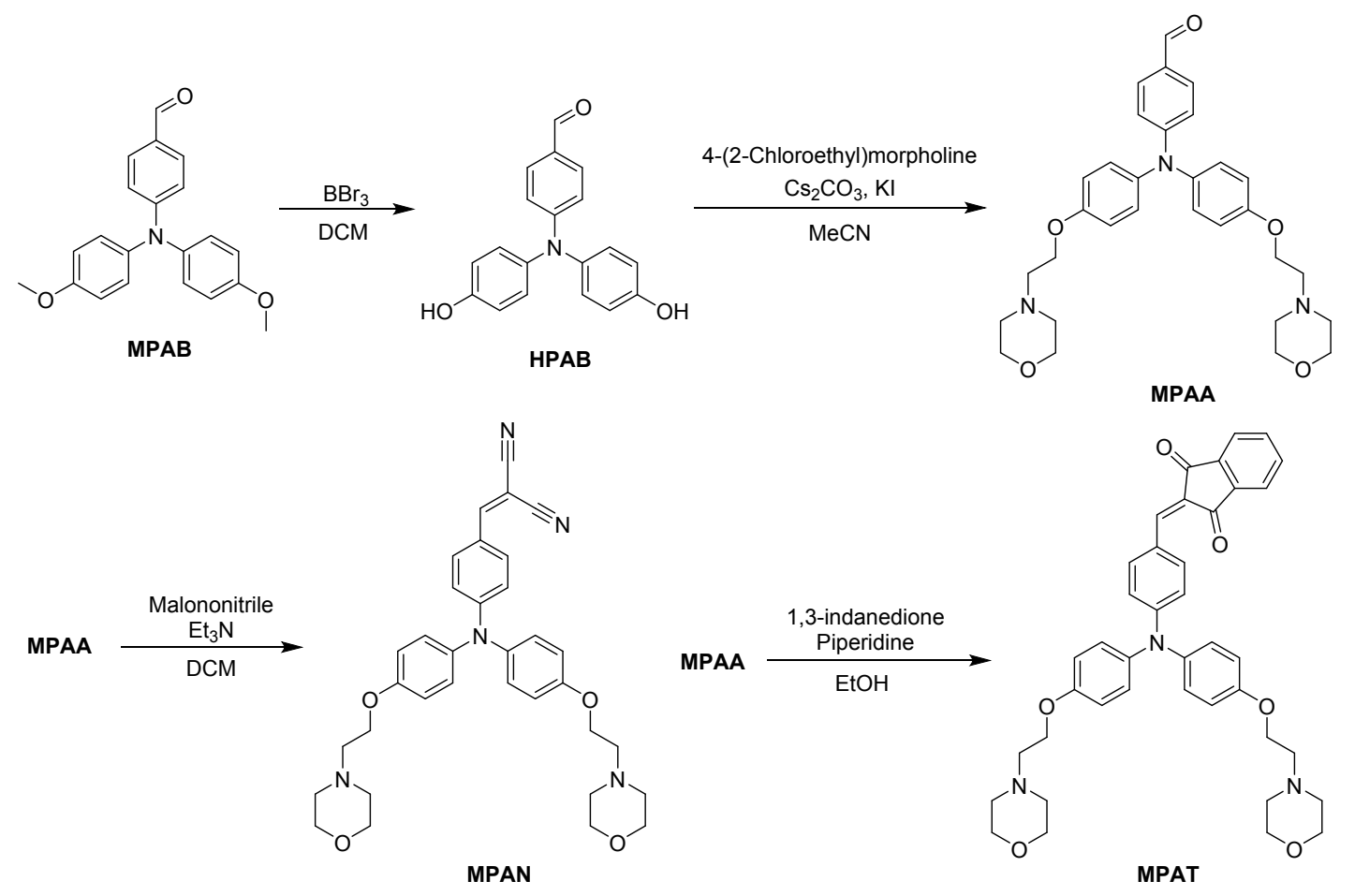

Scheme S1. The synthetic scheme of MPAA, MPAN and MPAT. 


\section{Analysis and fluorescence bio-imaging figures}
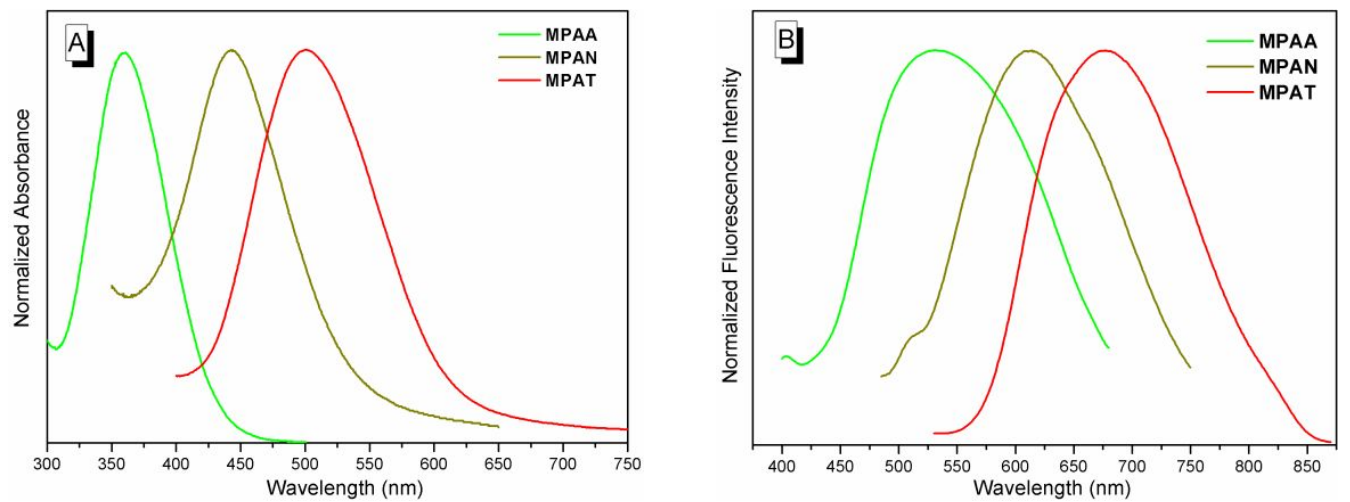

Figure S1. Normalized absorption (A) and fluorescence emission (B) spectra of MPAA, MPAN and MPAT $(20 \mu \mathrm{M})$ in water.
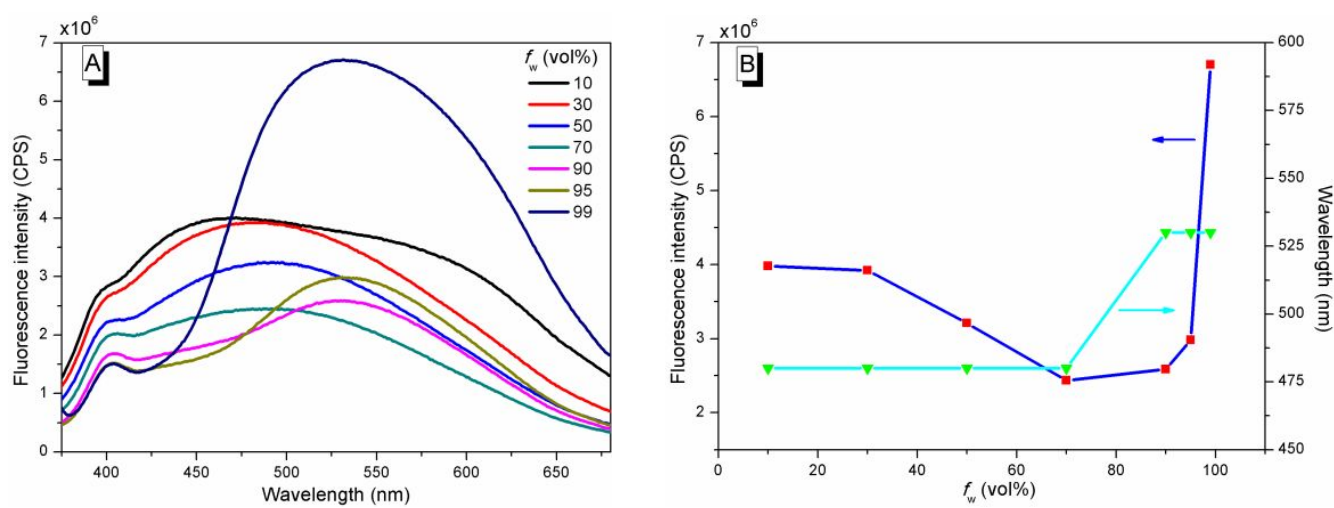

Figure S2. The emission spectra (A) of MPAA $(20 \mu \mathrm{M})$ in $\mathrm{DMF} / \mathrm{H}_{2} \mathrm{O}$ mixture solutions with different water fractions $\left(f_{\mathrm{w}}\right)$; Changes of fluorescence intensity and emission wavelength vs the $f_{\mathrm{w}}$ values for MPAA (B).
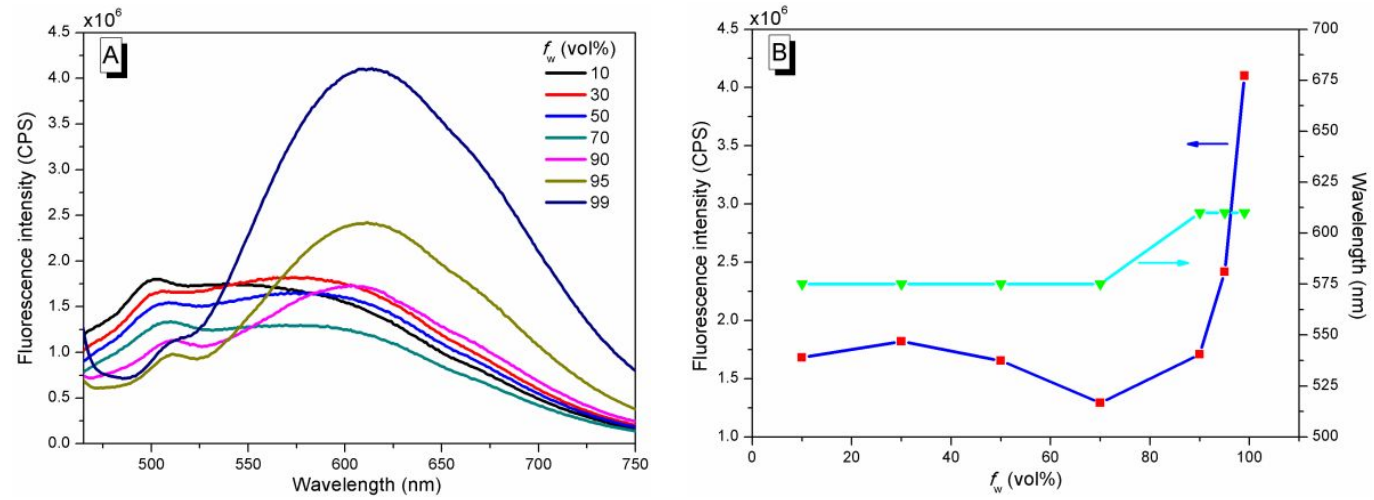

Figure S3. The emission spectra (A) of MPAN $(20 \mu \mathrm{M})$ in $\mathrm{DMF} / \mathrm{H}_{2} \mathrm{O}$ mixture solutions with different water fractions $\left(f_{\mathrm{w}}\right)$; Changes of fluorescence intensity and emission wavelength vs the $f_{\mathrm{w}}$ values for MPAN (B). 

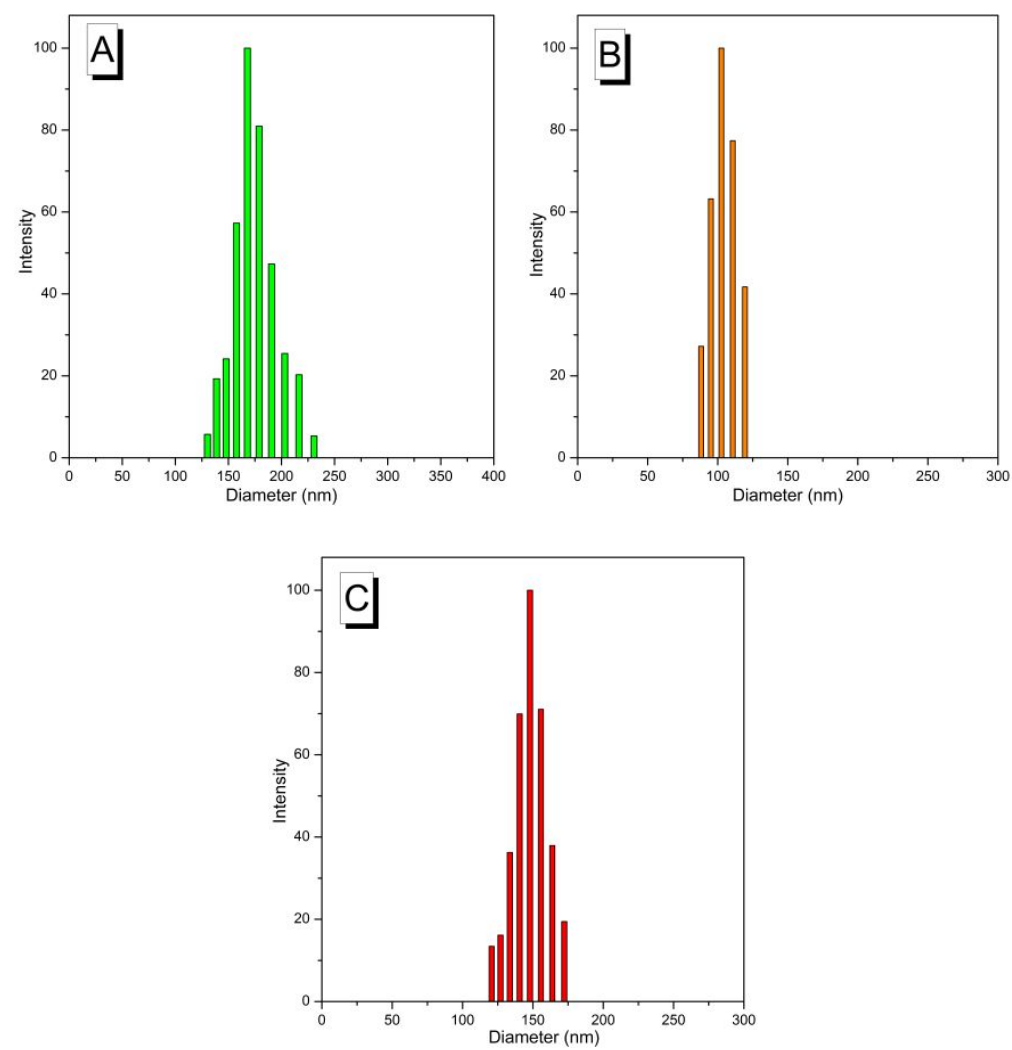

Figure S4. Particle size distributions of MPAA (A), MPAN (B) and MPAT (C) aggregates in water solution.

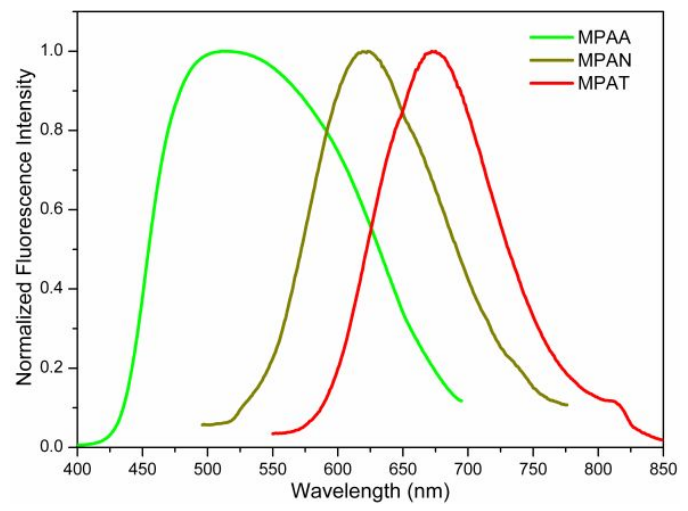

Figure S5. Normalized fluorescent emission of MPAA, MPAN and MPAT in solid state.
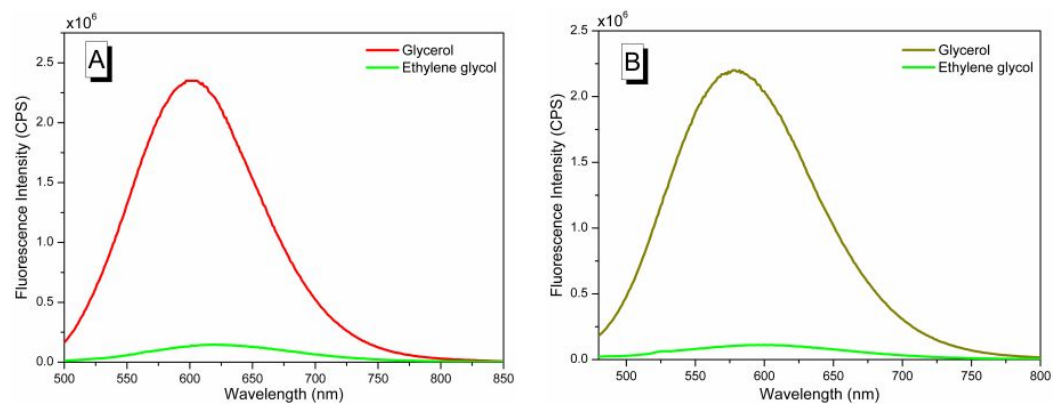


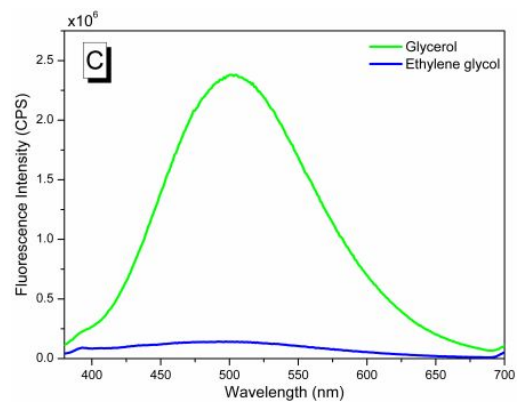

Figure S6. The emission spectra of AIEgens $(20 \mu \mathrm{M})$ in ethylene glycol and glycerol. (A: MPAT; B: MPAN; C: MPAA)

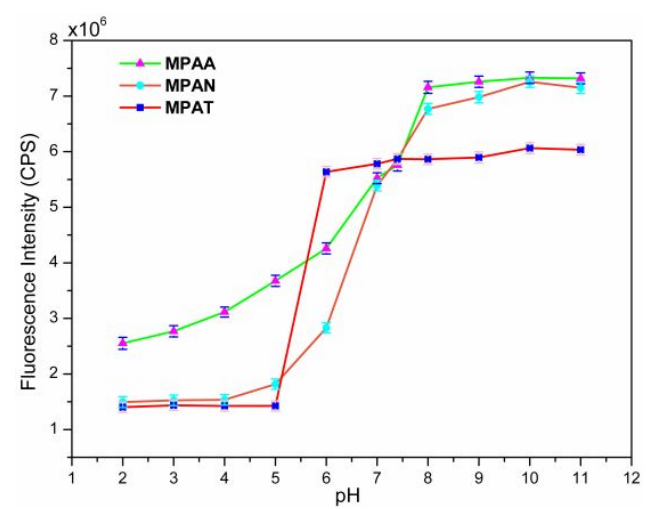

Figure S7. The fluorescence responses of MPAA, MPAN and MPAT $(20 \mu \mathrm{M})$ at different $\mathrm{pH}$.

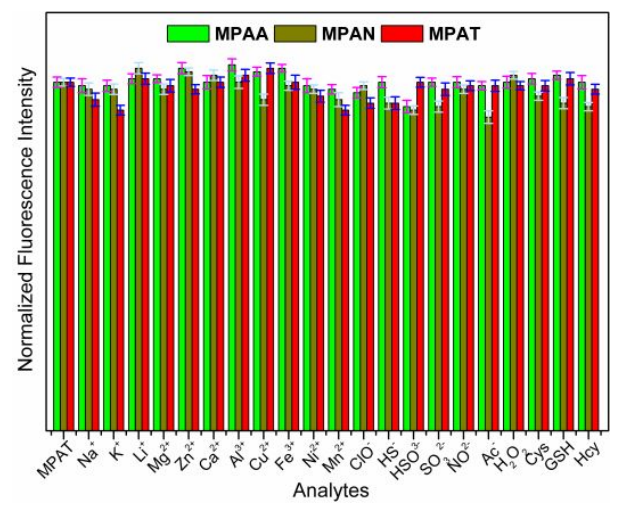

Figure S8. Fluorescence intensity of MPAA, MPAN and MPAT $(20 \mu \mathrm{M})$ changes toward 100 $\mu \mathrm{M}$ various analytes. 


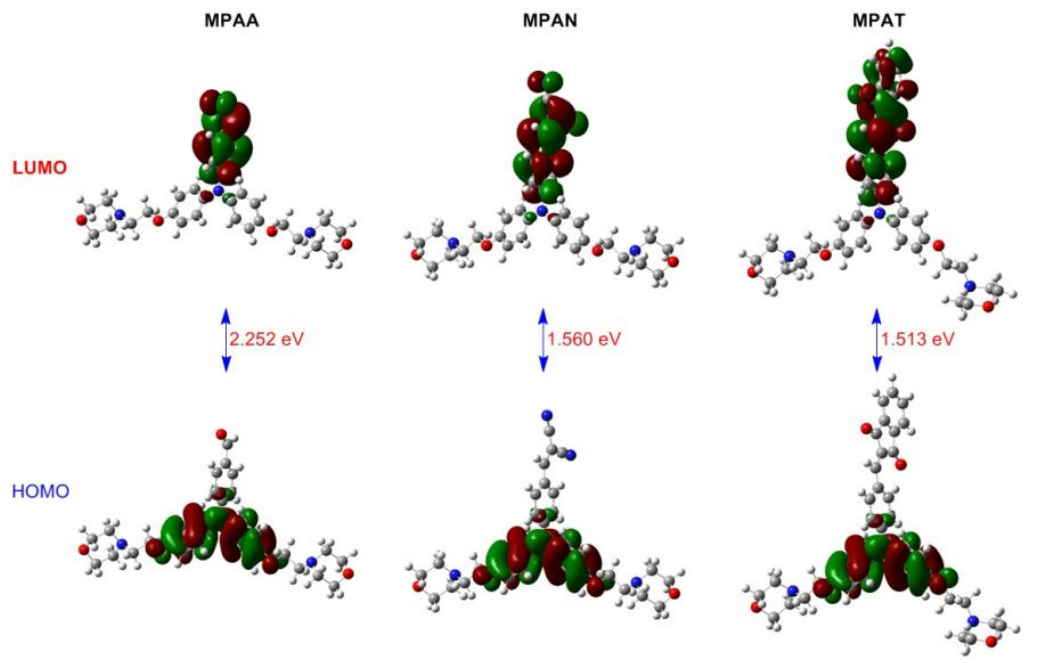

Figure S9. Optimized geometries and molecular orbitals of HOMO and LUMO levels of the AIEgens.

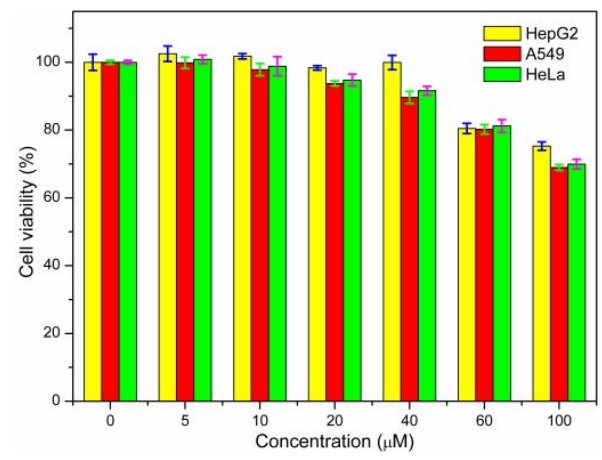

Figure S10. Cell viabilities of HepG2, A549 and HeLa cells after incubation with different concentrations of MPAT $(0,5,10,20,40,60$ and $100 \mu \mathrm{M})$ for $24 \mathrm{~h}$.

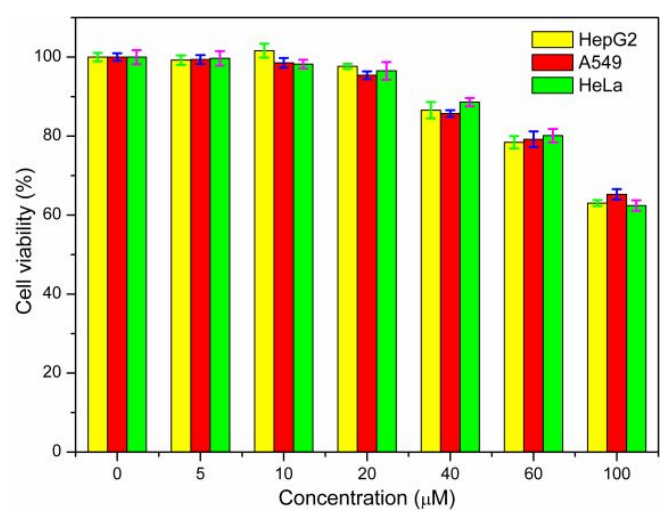

Figure S11. Cell viabilities of HepG2, A549 and HeLa cells after incubation with different concentrations of MPAA $(0,5,10,20,40,60$ and $100 \mu \mathrm{M})$ for $24 \mathrm{~h}$. 


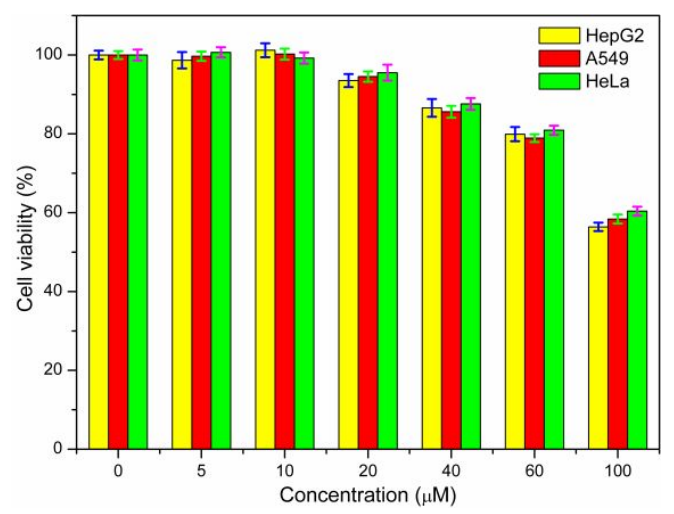

Figure S12. Cell viabilities of HepG2, A549 and HeLa cells after incubation with different concentrations of MPAN $(0,5,10,20,40,60$ and $100 \mu \mathrm{M})$ for $24 \mathrm{~h}$.
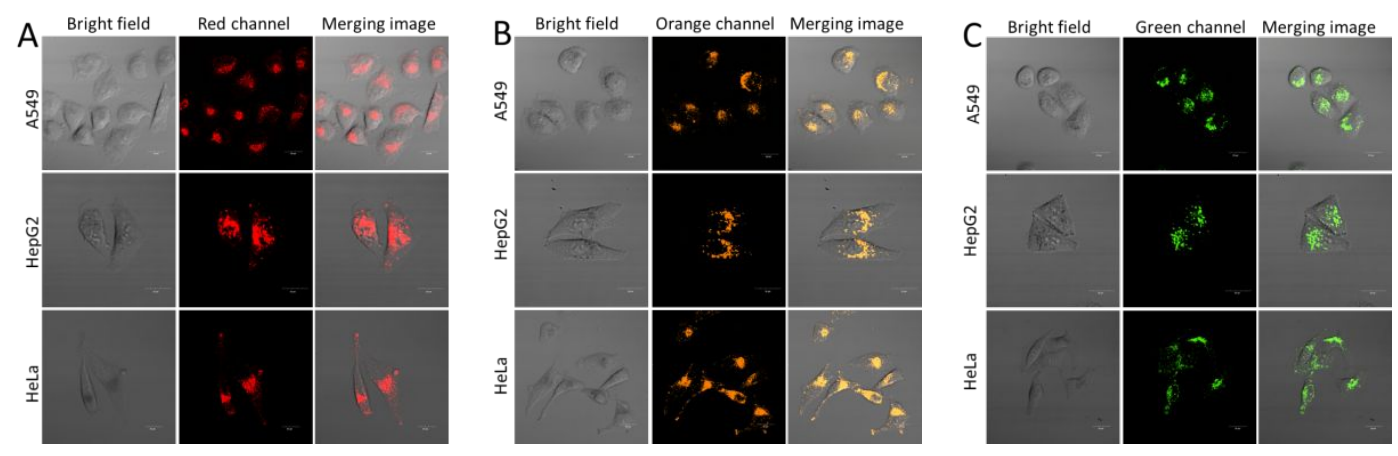

Figure S13. The fluorescence imaging of AIEgens $(20 \mu \mathrm{M})$ in A549, HepG2 and HeLa cells, A:

MPAT; B: MPAN; C: MPAA. (Scale bar: $20 \mu \mathrm{m}$ )

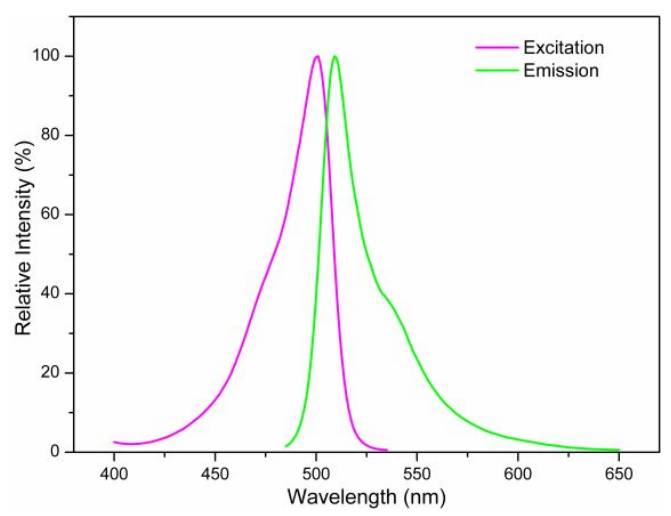

Figure S14. Excitation and Fluorescence Emission Spectra of LysoTracker Green DND-26 (Data from ThermoFisher Scientific). 


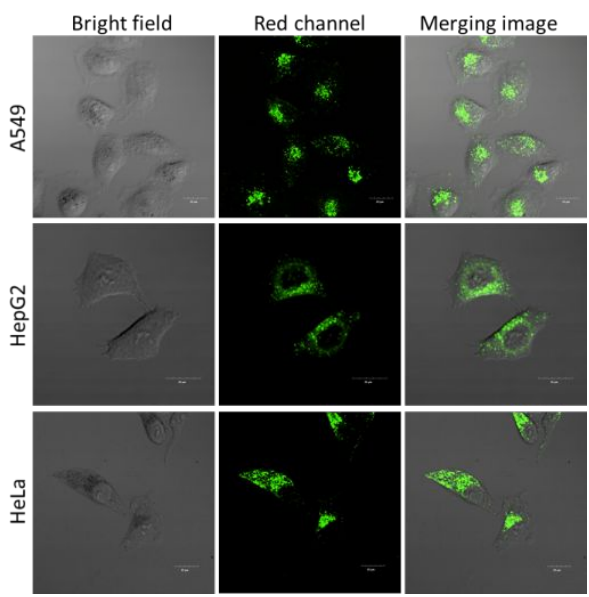

Figure S15. The fluorescence imaging of LysoTracker Green DND-26 (50 nM) in A549, HepG2 and HeLa cells. (Scale bar: $20 \mu \mathrm{m}$ )

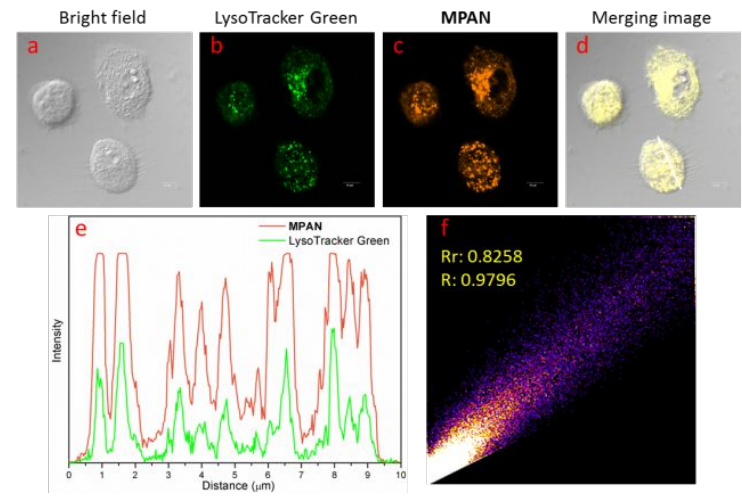

Figure S16. a-d: Confocal images of A549 cells with the incubation of MPAN $(20 \mu \mathrm{M})$ for 30 min followed by co-staining with LysoTracker Green DND-26 (50 nM) for 5 min. e: Intensity profile of ROIs analysis of A549 cells in the red and green channels. f: Intensity scatter plot of the green and red channels. (Scale bar: $10 \mu \mathrm{m}$ )

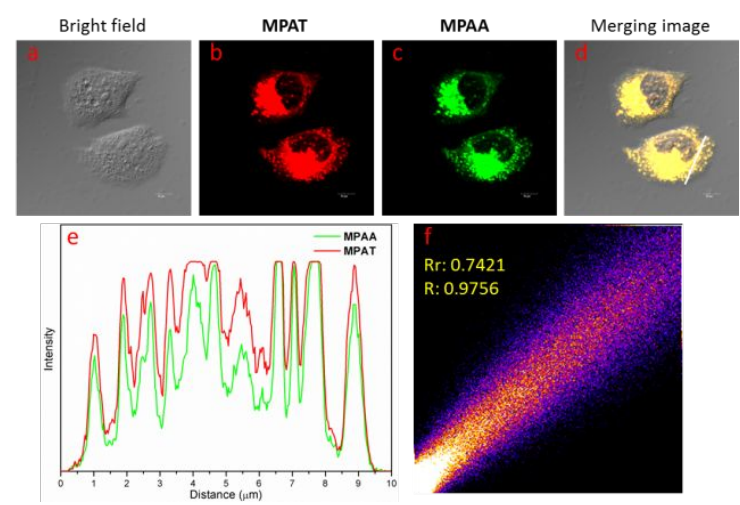

Figure S17. a-d: Confocal images of A549 cells with the incubation of MPAA $(20 \mu \mathrm{M})$ for 30 min followed by co-staining with MPAT $(20 \mu \mathrm{M})$ for 5 min. e: Intensity profile of ROIs analysis of A549 cells in the red and green channels. f: Intensity scatter plot of the green and red channels.

(Scale bar: $10 \mu \mathrm{m}$ )

\section{Tables of photophysical data of AIEgens}


Table S1. Photophysical properties of MPAA in different solvents.

\begin{tabular}{cccccccc}
\hline Compd & Solvent & $\lambda_{\mathrm{ab}}{ }^{\mathrm{a}}(\mathrm{nm})$ & $\begin{array}{c}\varepsilon \\
{[\mathrm{L} /(\mathrm{mol} \cdot \mathrm{cm})]}\end{array}$ & $\lambda_{\mathrm{em}}{ }^{\mathrm{b}}(\mathrm{nm})$ & $\begin{array}{c}\text { Stokes } \\
\text { shift }(\mathrm{nm})\end{array}$ & $\Phi_{\mathrm{Fl}}{ }^{\mathrm{c}}(\%)$ & $\tau^{\mathrm{d}}(\mathrm{ns})$ \\
\hline & DMF & 345 & 22600 & 475 & 123 & 0.07 & 1.34 \\
& Water & 360 & 20300 & 530 & 178 & 12.52 & 2.80 \\
MPAA & Solid & 374 & - & 515 & 163 & 23.65 & 4.32 \\
& EG & 360 & 21800 & 500 & 148 & 1.54 & 1.68 \\
& $\mathrm{VG}$ & 364 & 21100 & 503 & 151 & 9.32 & 2.56 \\
\hline
\end{tabular}

${ }^{\text {a }}$ Maximum absorption wavelength. ${ }^{\mathrm{b}}$ Maximum emission wavelength. ${ }^{\mathrm{c}}$ Absolute quantum yield. ${ }^{\mathrm{d}}$ Average fluorescence lifetime.

Table S2. Photophysical properties of MPAN in different solvents.

\begin{tabular}{|c|c|c|c|c|c|c|c|}
\hline Compd & Solvent & $\lambda_{\mathrm{ab}}^{\mathrm{a}}(\mathrm{nm})$ & $\begin{array}{c}\varepsilon \\
{[\mathrm{L} /(\mathrm{mol} \cdot \mathrm{cm})]}\end{array}$ & $\lambda_{\mathrm{em}}^{\mathrm{b}}(\mathrm{nm})$ & $\begin{array}{c}\text { Stokes } \\
\text { shift }(\mathrm{nm})\end{array}$ & $\Phi_{\mathrm{Fl}}^{\mathrm{c}}(\%)$ & $\tau^{\mathrm{d}}(\mathrm{ns})$ \\
\hline \multirow{5}{*}{ MPAN } & DMF & 438 & 15500 & 550 & 95 & 0.05 & 1.29 \\
\hline & Water & 445 & 13150 & 615 & 160 & 2.53 & 1.94 \\
\hline & Solid & 445 & - & 623 & 68 & 4.85 & 3.15 \\
\hline & $\mathrm{EG}$ & 445 & 15250 & 600 & 145 & 0.55 & 1.39 \\
\hline & VG & 445 & 14450 & 578 & 123 & 2.22 & 1.64 \\
\hline
\end{tabular}




\section{The characterization data of AIEgens.}

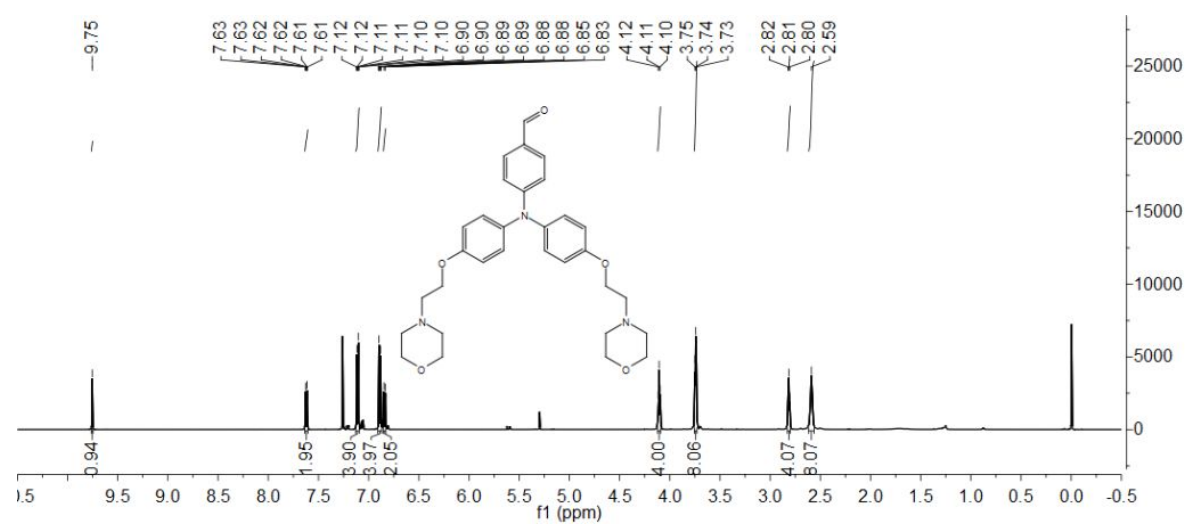

${ }^{1} \mathrm{H}$ NMR spectra of MPAA

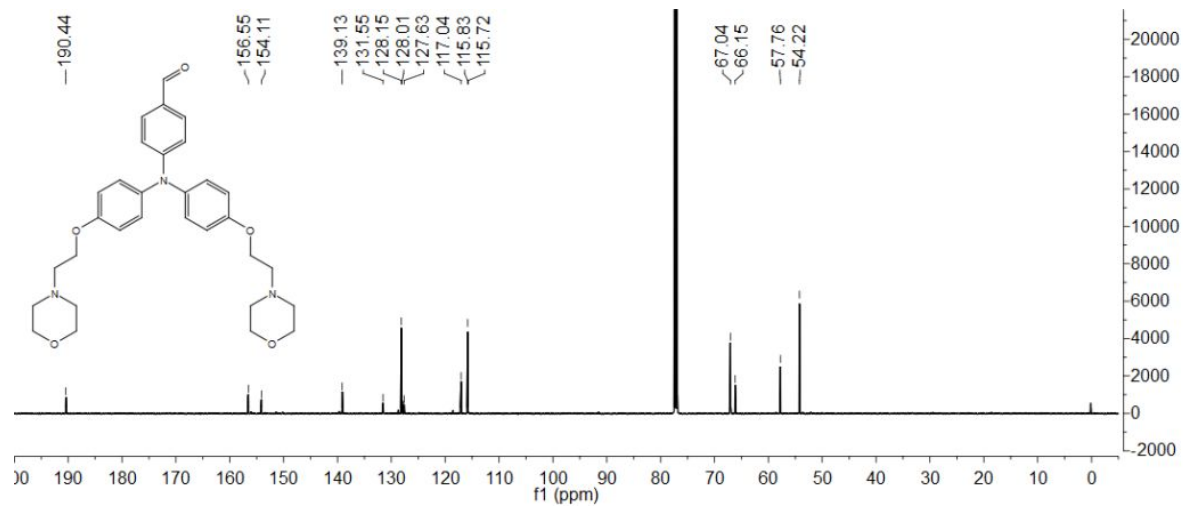

${ }^{13} \mathrm{C}$ NMR spectra of MPAA

MS Spectrum

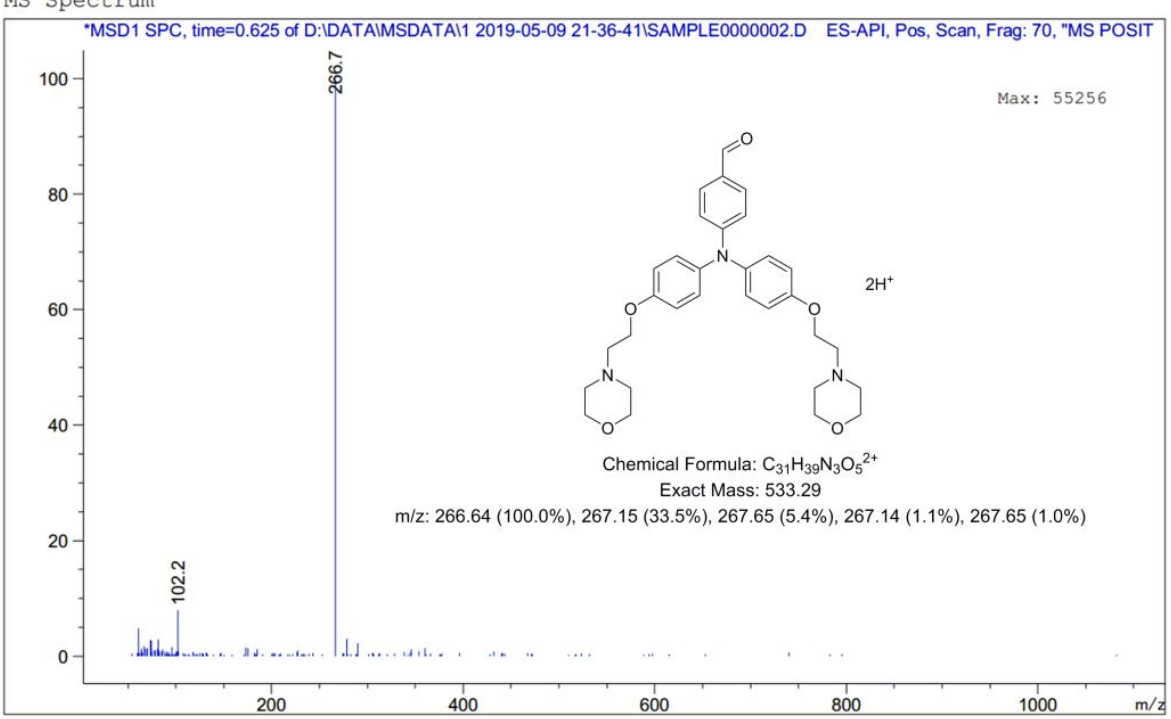

MS spectra of MPAA 


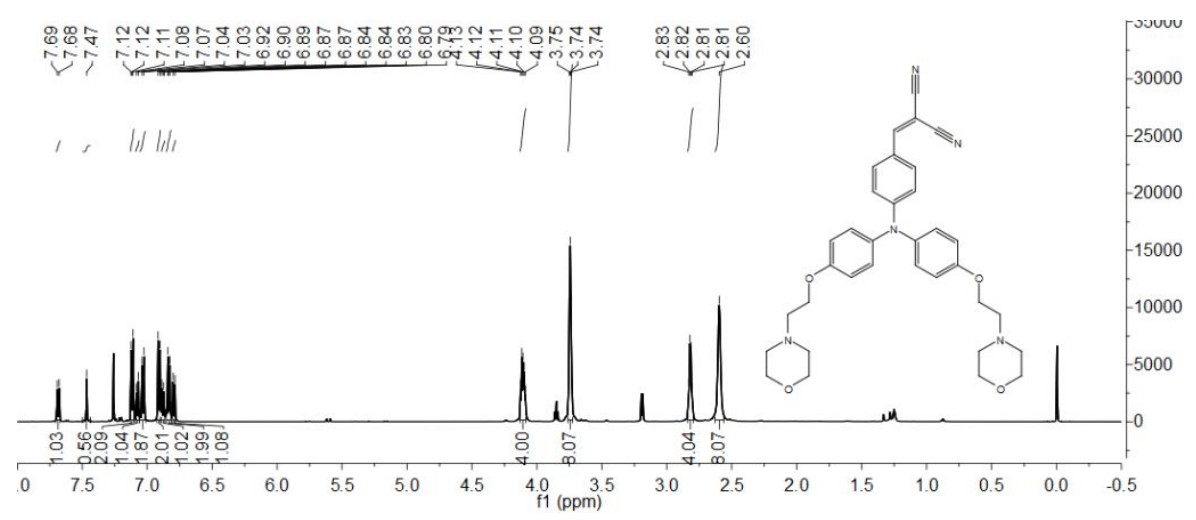

${ }^{1} \mathrm{H}$ NMR spectra of MPAN

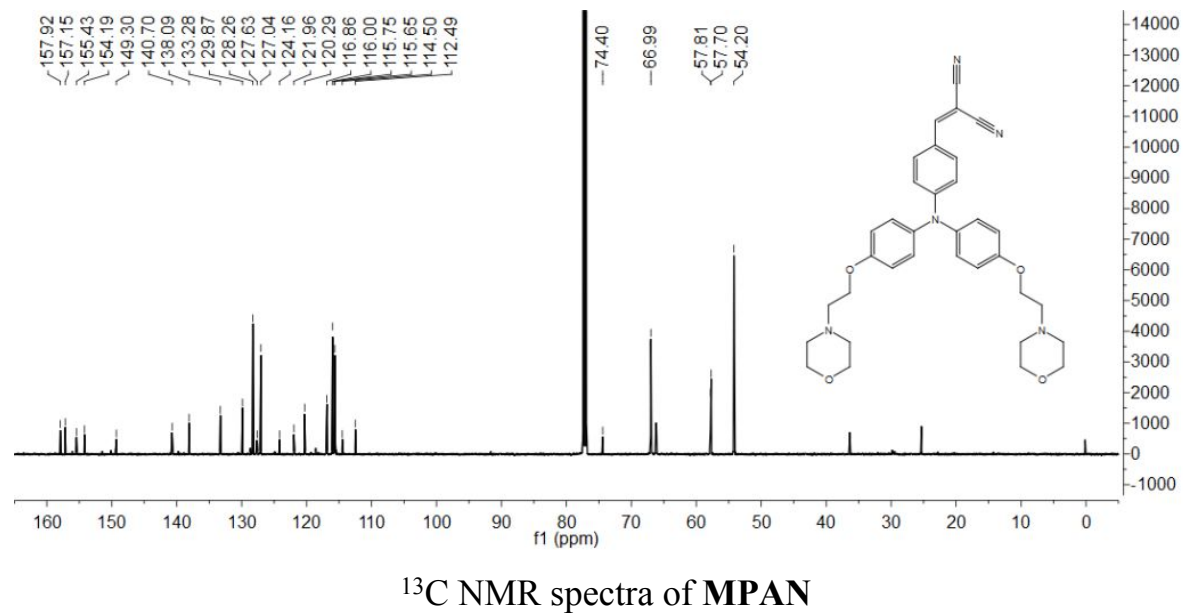

MS Spectrum

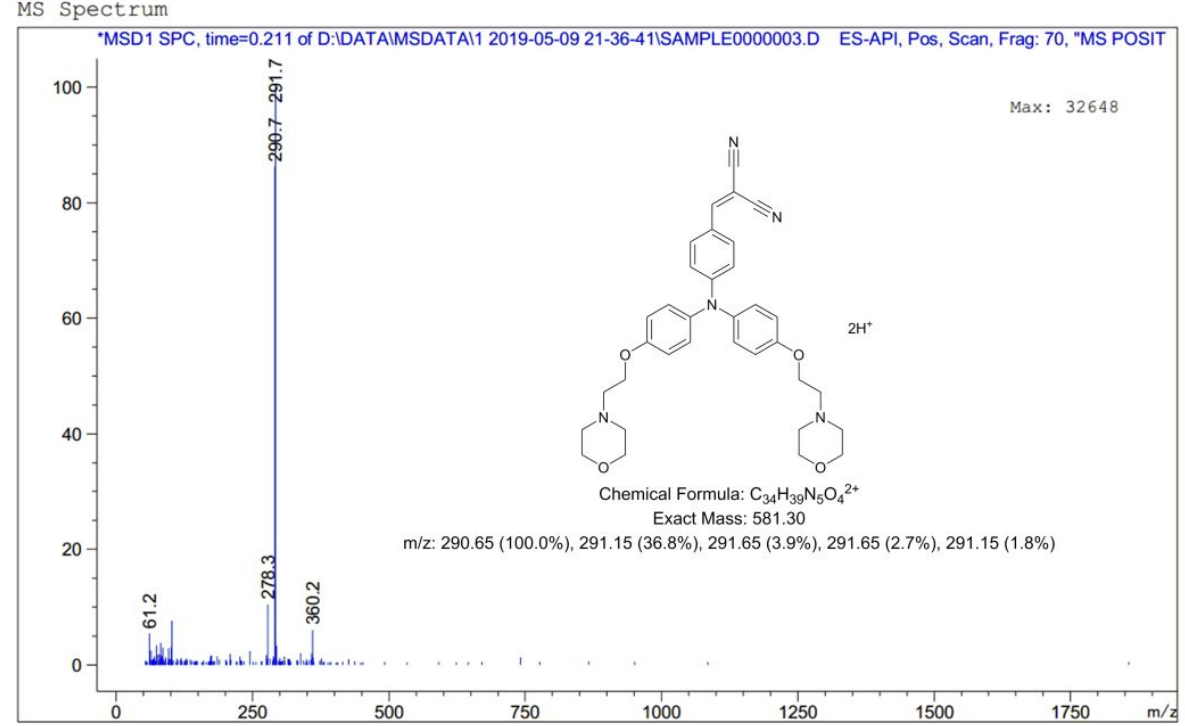

MS spectra of MPAN 


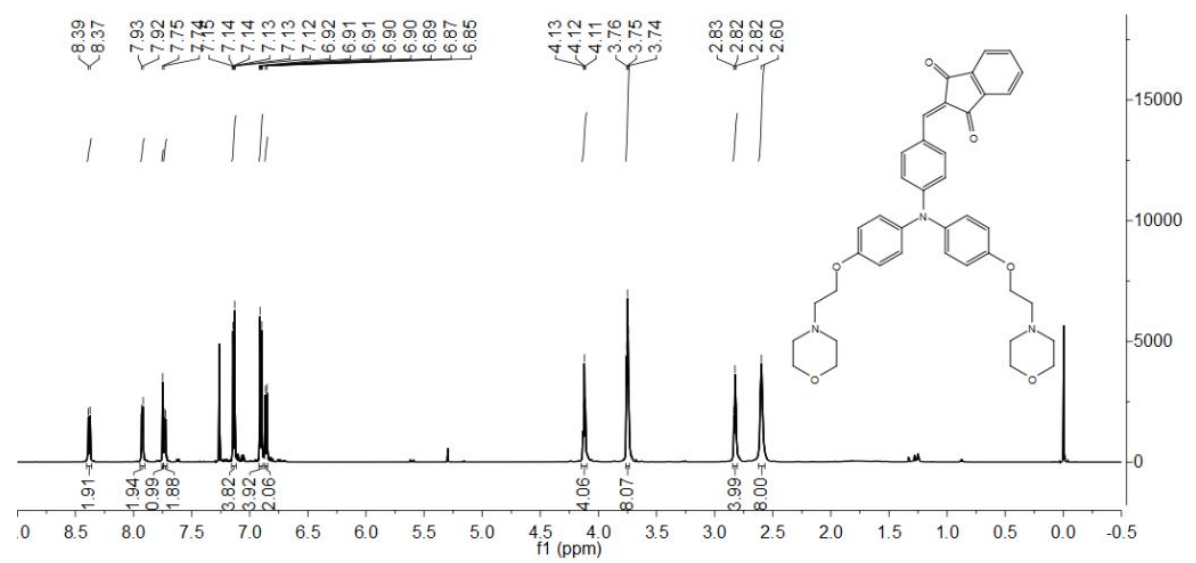

${ }^{1} \mathrm{H}$ NMR spectra of MPAT

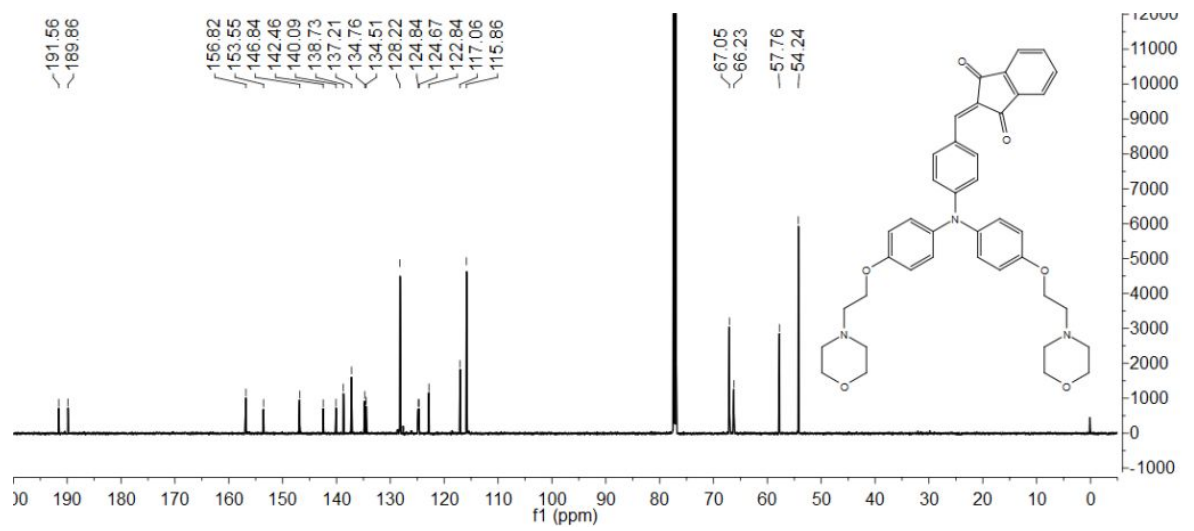

${ }^{13} \mathrm{C}$ NMR spectra of MPAT

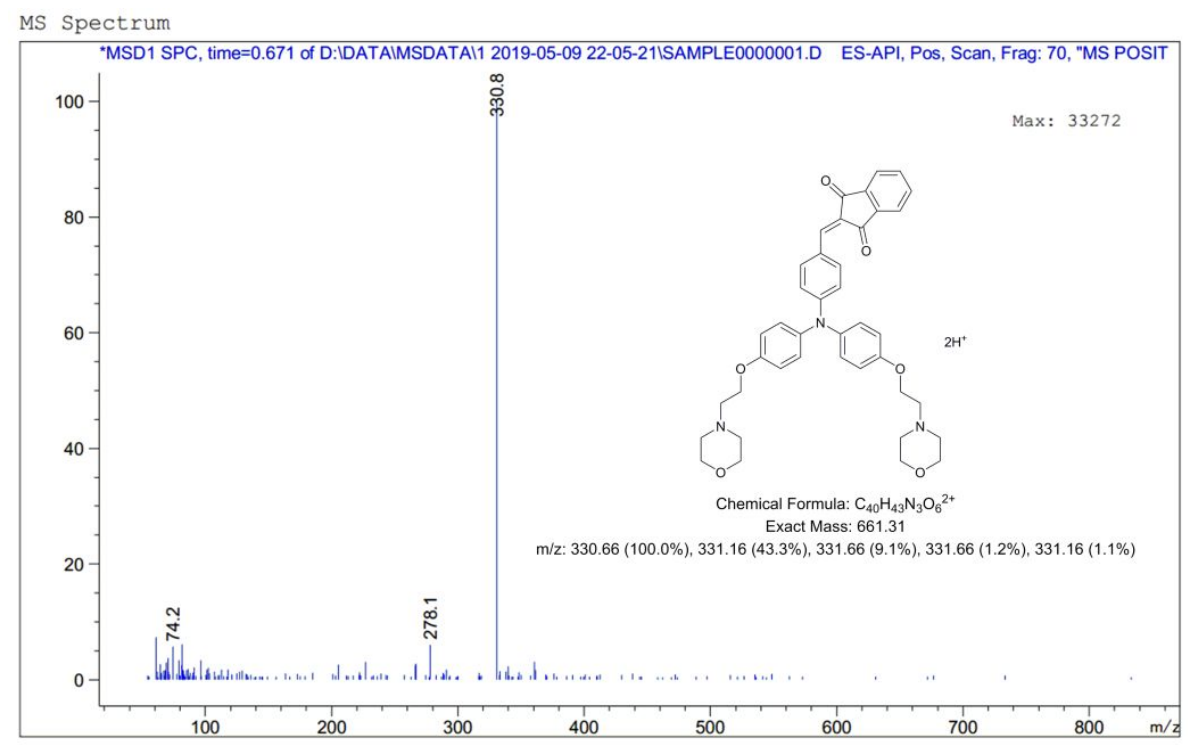

MS spectra of MPAT

\section{Reference}

[1] Y. Li, H. Zhou, W. Chen, G. Sun, L. Sun, J. Su, A simple AIE-based chemosensor for highlysensitive and selective detection of $\mathrm{Hg}^{2+}$ and $\mathrm{CN}^{-}$, Tetrahedron, 72 (2016) 5620-5625. 